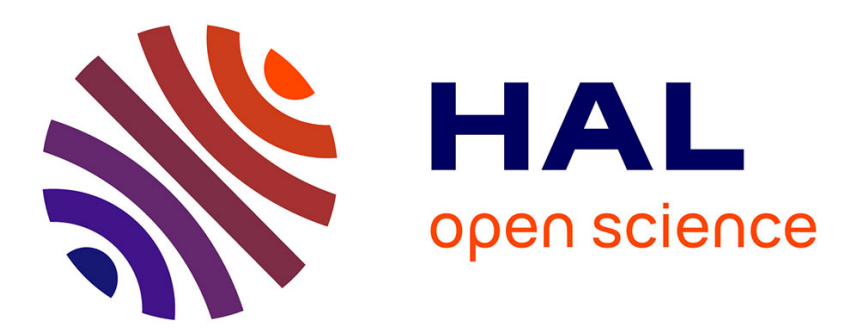

\title{
Do artificial structures alter marine invertebrate genetic makeup?
}

Cécile Fauvelot, Federica Costantini, Massimiliano Virgilio, Marco Abbiati

\section{To cite this version:}

Cécile Fauvelot, Federica Costantini, Massimiliano Virgilio, Marco Abbiati. Do artificial structures alter marine invertebrate genetic makeup?. Marine Biology, 2012, 159, pp.2797 - 2807. 10.1007/s00227012-2040-4 . ird-03044159

\section{HAL Id: ird-03044159 \\ https://hal.ird.fr/ird-03044159}

Submitted on 7 Dec 2020

HAL is a multi-disciplinary open access archive for the deposit and dissemination of scientific research documents, whether they are published or not. The documents may come from teaching and research institutions in France or abroad, or from public or private research centers.
L'archive ouverte pluridisciplinaire HAL, est destinée au dépôt et à la diffusion de documents scientifiques de niveau recherche, publiés ou non, émanant des établissements d'enseignement et de recherche français ou étrangers, des laboratoires publics ou privés. 


\title{
Do artificial structures alter marine invertebrate genetic makeup?
}

\author{
Cécile Fauvelot $\cdot$ Federica Costantini $\cdot$ \\ Massimiliano Virgilio • Marco Abbiati
}

Received: 4 April 2012/Accepted: 2 August 2012/Published online: 29 August 2012

(C) Springer-Verlag 2012

\begin{abstract}
Human-made structures are increasingly built in marine coastal habitats for a variety of purposes. Offshore oil and gas production platforms are among the largest examples. Yet, biological effects of these increasing density artificial substrata are under evaluated. The objective of our study is to investigate the possible role of offshore platforms in modifying the genetic composition of populations of natural rocky shores species. The serpulid Pomatoceros triqueter was used as a model, and genetic variation was assessed using a $419 \mathrm{bp}$ fragment of the mtDNA COI gene in samples collected on eleven offshore gas platforms, on one coastal buoy on the sandy shore and in four sites located on natural rocky shores in the Adriatic Sea. Deep phylogenetic lineages were uncovered over all samples. Nucleotide diversity and mean number of pairwise differences
\end{abstract}

Communicated by T. Reusch.

C. Fauvelot · F. Costantini - M. Abbiati

Dipartimento di Biologia Evoluzionistica Sperimentale,

Centro Interdipartimentale di Ricerca per le Scienze

Ambientali, University of Bologna, 48123 Ravenna, Italy

C. Fauvelot $(\square)$

Institut de Recherche pour le Développement, UR227,

DYNECAR, EA 926, Laboratoire de Biologie Marine,

Université des Antilles et de la Guyane,

97159 Pointe-à-Pitre cedex, Guadeloupe

e-mail: cecile.fauvelot@ird.fr

M. Virgilio

Royal Belgian Institute of Natural Sciences,

1000 Brussels, Belgium

M. Virgilio

Royal Museum for Central Africa, 3080 Tervuren, Belgium

M. Abbiati

ISMAR CNR, Via Gobetti 101, I, 40129 Bologna, Italy among haplotypes were significantly smaller in offshore platform samples compared to rocky shores samples. No significant genetic structure was observed over all samples. We found direct evidence of lower genetic diversity on platforms confirming that, although artificial structures attract and support species typical of hard bottoms, they are not analogues of natural rocky habitats.

\section{Introduction}

Disturbances related to human activities (e.g. habitat loss and fragmentation, global environmental change, overexploitation and other effects due to fishing, pollution and tourism) are worldwide recognized as a major threat to marine ecosystems (Lotze et al. 2006; Worm et al. 2006; Airoldi and Beck 2007). Among recognized anthropogenic pressures, the impact of artificial structures introduction has received increased attention in the recent decades (see Bulleri and Chapman 2010 for a review).

Artificial hard structures are most often built in sandy areas that, as a result, generate unnatural changes in species composition, abundance and diversity of native soft-bottom assemblages (Connell 2001; Martin et al. 2005; Airoldi et al. 2005; Bulleri 2005; Moschella et al. 2005; Bulleri and Chapman 2010). Besides these modifications at the community and species level, artificial structures also play a role at the population level, providing new colonizing substrata (Page et al. 2006; Fauvelot et al. 2009). Indeed, genetic diversity on these artificial structures may be inclined to deep changes, as recently observed for the limpet Patella caerulea collected on breakwaters (Fauvelot et al. 2009). Since genetic diversity can affect the species productivity, population growth and stability, as well as inter-specific interaction within community, and ecosystem-level processes (Hughes et al. 2008), this 
parameter is crucial for species survival in highly variable environments or those subject to rapid anthropogenic changes (Reusch et al. 2005). In addition, since all benthic organisms directly associated with artificial structures rely on a pelagic larval phase to disperse and colonize new habitats, artificial structures may enhance connectivity among differentially adapted populations, (i.e. artificial structures may serve as "stepping stones" for hard-bottom species) which may ultimately lead to negative effects of biogenic homogenization (see Olden et al. 2004 for a review).

Offshore oil and gas production platforms are among the largest artificial structures in the marine environment. They are associated with several environmental issues, related to their installation, daily shipping movements, extraction activities, maintenance and final decommissioning (Grant and Briggs 2002; Fabi et al. 2002; Page et al. 1999, 2006; Bomkamp et al. 2004; Terlizzi et al. 2008). The north Adriatic Sea is one of the major fields for extraction of natural gas in the Mediterranean basin (Teatini et al. 2000). Since 1950, more than 100 platforms (supplying over $70 \%$ of the total Mediterranean gas production) have been built over an area of $6,400 \mathrm{~km}^{2}$. These structures constitute most of the hard substrate in this sandy region and provide suitable habitat for the development of massive mussel (Mytilus galloprovincialis) beds, which are commercially exploited on permit from the petroleum companies (Fabi et al. 2002).

Despite the extent of these offshore activities in the North Adriatic Sea, few ecological impact studies have been carried out, and these have focussed on possible changes in the physiology, composition and structure of benthic and pelagic assemblages associated with the presence of offshore platforms (Relini et al. 1998; Crema et al. 2001; Ponti et al. 2002; Fabi et al. 2004; Consoli et al. 2007; Gorbi et al. 2008, 2009). However, so far, no study has investigated the genetic consequences of the platforms colonization on populations of natural rocky shores species. The goal of our study was to examine the potential consequences of the presence of offshore platforms on the genetic diversity and structure of natural rocky shore organisms. During a preliminary survey conducted in July 2005, benthic organisms have been collected and identified from three offshore platforms in order to select several target species as model organisms. The primary objectives of this survey were to identify the fauna that could be sampled on the legs of the offshore platforms, and from these, select the ones that could be sampled in sufficient numbers to conduct reliable analysis. Among macrobenthic organisms, we found a majority of mussels (Mytilus galloprovincialis), serpulids (Pomatoceros triqueter and in lower densities Serpula vermicularis), oysters (Ostrea edulis and Crassostrea gigas), and in lower densities barnacles, brittle stars and errant polychaetes (Nereididae). A detailed description of the platform fauna at Ravenna can be found in Relini et al. (1998) and in Ponti et al. (2002). Due to health and safety regulations, we were not authorized to sample benthic organisms from the platforms ourselves, and we had to rely on what was sampled by the professional divers harvesting mussels on the legs of platforms. We chose to discard Mytilus galloprovincialis as a target species to avoid a possible harvesting impact on genetic diversity, and thus focused our sampling effort and genetic analyses on the second most common species on the platforms, Pomatoceros triqueter (Linnaeus, 1767), a benthic worm typical of the fouling community (Crisp 1974).

The serpulid genus Pomatoceros are sessile, tubicolous and filter-feeders, occurring on a variety of substrata at depths ranging from low water intertidal into the shallow benthic, with a wide geographical distribution from cold temperate latitudes to the equator in the northern hemisphere (Crisp and Ekaratne 1984). Pomatoceros spp. have feeding, planktonic larvae (Kupriyanova 2003) and are capable of reproducing throughout the year (Castric-Fey 1984). The larval duration of Pomatoceros triqueter varies between 15 days and 4 weeks, depending on the temperature, as for its sister species Pomatoceros lamarckii (Castric-Fey 1984; Hayward and Ryland 1995; Cotter et al. 2003). P. triqueter and P. lamarckii (co-occurring in the Mediterranean Sea, though not encountered on the platforms, Ponti et al. 2002, personal observations) can be distinguished morphologically by differences in their operculum structure; in $P$. triqueter, the operculum is convex, cone-shaped and obliquely mounted on the peduncle, whereas in $P$. lamarckii, the operculum is concave, cup-shaped and mounted centrally on its stalk (Zibrowius 1968).

In this study, we investigated the genetic diversity and structure of Pomatoceros triqueter collected on eleven offshore gas platforms, on one costal buoy and in four sites located on natural rocky shores in the Adriatic Sea. We specifically tested (a) whether the genetic diversity of populations on platforms was reduced compared to populations on natural rocky shores, as could be expected from the recent founding of the platforms, or alternatively enhanced if the platform populations act as reservoir of genetic diversity and (b) for differences in the genetic structuring of populations between platform and natural shores.

\section{Materials and methods}

\section{Sampling}

The sampling was conducted in the Adriatic Sea, on natural rocky shores, and more intensively on gas platforms. Sampling was conducted between May and August 2006. Platforms have been selected according to their location (in order to cover the range of platforms inter-distances) and the 
possibility to sample with vessels. Sampling was completed by the use of the vessels from the Cooperative Society 'La Romagnola' which conducted daily sampling on the platforms for mussels harvesting. In total, ten effective platforms have been sampled (Agostino-A, Amelia-D, Anemone-B, Angelina, Antonella, Armida, Cervia-K, Garibaldi-C, Porto Corsini Est-80bis and Porto Corsini C), as well as the wreck platform Paguro (Fig. 1). For each platform, mussel beds collected by the professional divers were brought to the laboratory for sorting, and Pomatoceros triqueter tubes were detached from mussel shells.

Along the west shoreline of the Adriatic Sea, natural hard-bottom habitats, represented by isolated rocky promontories, interrupt large sandy coasts extending between the Friuli-Venezia Giulia and Puglia regions (NE and SE of Italy, respectively). The largest of these rocky promontories are Sistiana/Miramare (Friuli-Venezia Giulia), Gabicce (Emilia-Romagna), Conero (Marche) and Gargano (Puglia). Sampling along the Adriatic coasts was conducted

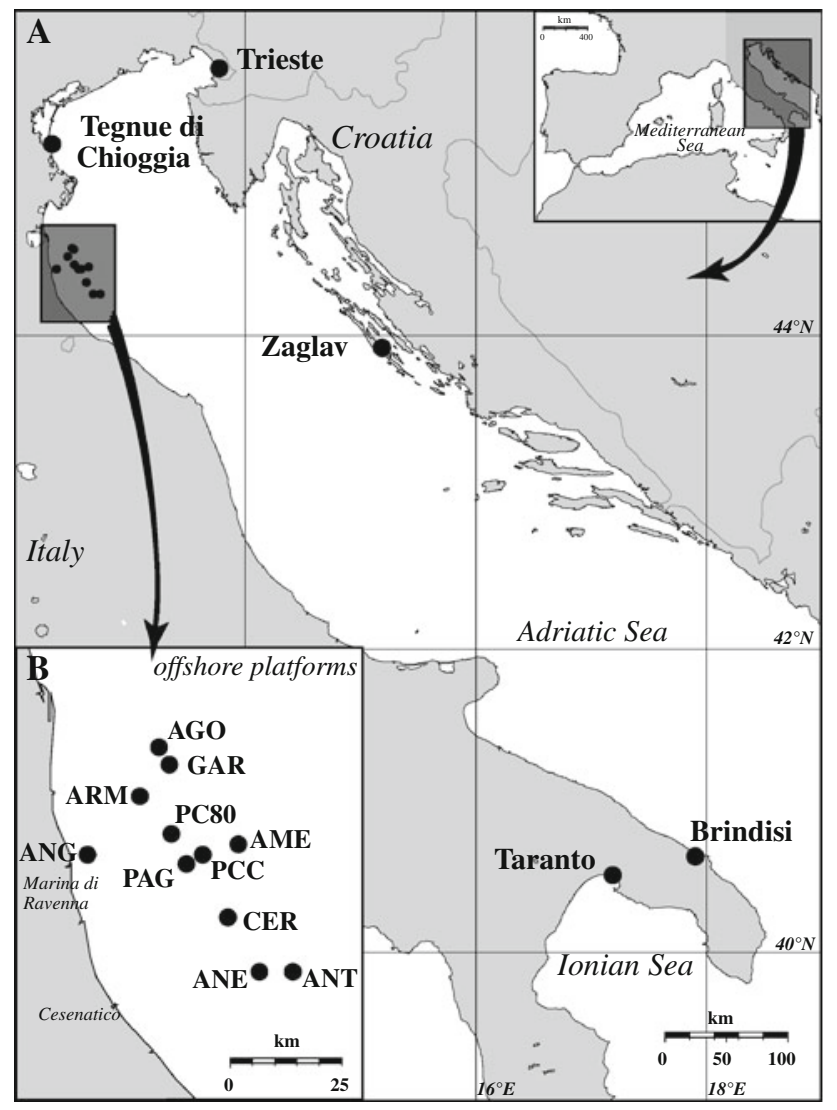

Fig. 1 Location of sampling sites $(A)$ along the coasts of Italy (Tegnue di Chioggia, Trieste, Brindisi, Taranto) and Croatia (Zaglav on the island of Dugi Otok) and $(B)$ from eleven offshore platforms off the coast of Ravenna ( $A G O$ Agostino-A, $A M E$ Amelia-D, $A N E$ Anemone-B, ANG Angelina, ANT Antonella, ARM Armida, CER Cervia-K, GAR Garibaldi-C, PC80 Porto Corsini Est-80bis, $P C C$ Porto Corsini C, PAG Paguro) along the sea shore by SCUBA diving in Trieste (Miramare), Tegnue di Chioggia, Ancona (Conero), Brindisi, Taranto and in Zaglav (on the Croatian island of Dugi Otok) where Pomatoceros triqueter were found on rocks (Fig. 1), except in Tegnue di Chioggia where $P$. triqueter were found on buoys delimiting the marine protected area. In Ancona, only Pomatoceros lamarckii was encountered and sampled. In Brindisi, the sampling consists mostly of $P$. lamarckii so that only few $P$. triqueter could be analysed.

\section{Molecular analysis}

Immediately after sampling, alive individual worms were placed at $4{ }^{\circ} \mathrm{C}$ for at least $3 \mathrm{~h}$ in order to facilitate the extraction of the worm body from its calcareous tube without damaging the body. Each collected worm was examined alive under binocular microscope for species identification and operculum shape notification. Each worm was then stored in individual Eppendorf tubes in $80 \% \mathrm{EtOH}$ and kept at $-20{ }^{\circ} \mathrm{C}$.

Genomic DNA was isolated from the caudal extremity of 11-29 individuals per site, using a cetyltrimethyl ammonium bromide (CTAB) protocol (Hillis and Moritz 1990). Specifically, each tissue sample was digested for $2 \mathrm{~h}$ at $65^{\circ} \mathrm{C}$ in $400 \mu \mathrm{l}$ of $2 \mathrm{X} \mathrm{CTAB}$ solution containing $3 \mathrm{U}$ of Proteinase K. Genomic DNA was extracted using Chloroform-Isoamyl Alcohol (24:1) and precipitated in $100 \%$ EtOH.

Like all non-model organisms, there were no markers available in the literature for Pomatoceros triqueter. We choose to test several universal primers amplifying mtDNA genes due to the development cost of microsatellites. Three genes could successfully be amplified in $P$. triqueter: COI, $12 \mathrm{~S}$ and $16 \mathrm{~S}$ (details available on request). We chose to conduct further genetic analysis using COI since this marker happened to be useful in revealing the genetic structure in two polychaete tubeworms (Jolly et al. 2006). Furthermore, the COI gene is more polymorphic than the $16 \mathrm{~S}$ and $12 \mathrm{~S}$ genes in annelids, both conserved within species (Jolly et al. 2006; Halanych and Janosik 2006). A 489-bp fragment of the mitochondrial DNA cytochrome oxidase I gene was amplified using the primers PtCOI-F (5'-GCT TGA GCC GGA ACC TGT GG-3') and PtCOI-R (5'-CCC CCA GCT AAT ACA GGA AC-3'), which were specifically designed for $P$. triqueter based on several sequences obtained using LCO1490 and HCO2198 (Folmer et al. 1994). Each $25 \mu \mathrm{l}$ PCR amplification contained 1X PCR buffer, $2 \mathrm{mM} \mathrm{MgCl}_{2}, 0.08 \mathrm{mM}$ of each dNTP, $3 \mu \mathrm{g}$ of BSA (Bovine Serum Albumin), $0.2 \mu \mathrm{M}$ of each PtCOI-F and PtCOI-R primer, $0.25 \mathrm{U}$ of Taq polymerase and about $30 \mathrm{ng}$ DNA. Amplified fragments were purified using the ExoSAP-IT kit (USB) following the 
manufacturer recommendations and cycle sequenced in both directions using Big Dye Terminator sequencing kit (Applied Biosystems). Sequences were run on an ABI 310 Genetic Analyser (Applied Biosystems). Forward and reverse sequences were compared for about $10 \%$ of the individuals in BioEdit (Hall 1999). Then, since forward and reverse sequences gave identical results, further sequences were obtained using only the forward primer (PtCOI-F). Individual sequences were then aligned by eye in GeneDoc (Nicholas and Nicholas 1997).

Data analysis

Haplotypes were identified, and their relative frequency within samples estimated using Arlequin version 3.11 (Excoffier et al. 2005). Genetic diversity within populations was estimated as haplotype diversity (Hd, Nei 1987), nucleotide diversity ( $\pi$, Nei 1987) and mean number of pairwise nucleotide differences between individuals ( $k$, Tajima 1983) using DnaSP 4.0 (Librado and Rozas 2009). Significant differences in genetic diversity ( $\mathrm{Hd}, \pi$ and $k$ ) between natural versus artificial habitats were tested using a Wilcoxon test.

Phylogenetic relationships among haplotypes were constructed using Bayesian analyses implemented in MrBayes 3.1 (Huelsenbeck and Ronquist 2001) and employed a cold chain and three incrementally heated chains with $T=0.1$. Starting trees for each chain were random, and the default values of MrBayes were chosen for all settings (including prior distributions). Each metropolis-coupled Markov chain Monte Carlo (MCMC) was run for 30 million generations, with trees sampled every 5,000 generations, and discarded the first 20 million generations (4,000 trees). By this time, the chains had converged to stable likelihood values $<0.01$. Posterior probabilities (PP) were used to assess clade supports. Analyses were run using the evolutionary model selected by the Akaike information criterion of MrModeltest (Nylander 2004). Pomatoceros larmarkii was used as outgroup: two specimens were sampled in Ancona (Marche, Italy, Adriatic Sea), and sequences were obtained using primers LCO1490 and $\mathrm{HCO} 2198$ as described above. Genetic divergences between supported monophyletic clades were estimated in Mega version 4 (Tamura et al. 2007) using the mean net nucleotide divergence ( $\mathrm{Nei}$ and $\mathrm{Li}$ 1979), defined as $d_{x y}-0.5\left(d_{x}+d_{y}\right)$, that subtracts the average 'within-group' divergence from the observed 'between-group' estimate and p-distance model.

A minimum spanning network (MSN) displaying evolutionary relationships between mtCOI haplotypes was constructed in TCS version 1.13 (Clement et al. 2000) to infer the most parsimonious branch connections at the $95 \%$ confidence level between haplotype pairs. The MSN was then redrawn by hand in Adobe ${ }^{\circledR}$ Illustrator $^{\circledR} 9.0$ (Adobe Systems Incorporated).
Data analyses of spatial genetic structure among populations were performed using Arlequin. Genetic divergences between pairwise samples were estimated using $\Phi$-Statistics $\left(\Phi_{\mathrm{ST}}\right.$ based on haplotype frequencies and molecular divergence using pairwise differences). $P$ values were obtained using a non-parametric permutation procedure with 10,000 permutations. In order to examine the partition of the genetic variance among samples based on the type of habitat or geographical locations, analyses of molecular variance (AMOVA) (Excoffier et al. 1992) were conducted in Arlequin.

\section{Results}

The amplification of a fragment of the mtDNA cytochrome oxidase I gene in a total of 350 individuals of Pomatoceros triqueter from 16 geographical samples resulted in fragments of 419 bp that could unambiguously be aligned and analysed. Among the 350 individuals sequenced, we identified 160 different haplotypes (GenBank accession numbers JX308620-JX308779), distinguished by 136 polymorphic sites and a total number of 162 mutations (i.e. some nucleotide positions carried more than two allelic states). Among the 16 sample sites, the number of haplotypes per sample ranged between 11 and 21 haplotypes. From the 160 observed haplotypes, only 21 were found in at least two individuals, and the 139 remaining haplotypes were singletons (i.e. haplotypes carried by only one individual, Table 1).

Over all the 16 samples, haplotype diversity ranged between 0.89 and 1 , nucleotide diversity between 0.020 and 0.048 and mean number of pairwise differences between 9.05 and 20.16. Excluding TEG for the comparisons (as it was neither a platform or a rocky shore sample), all three genetic diversity estimates were significantly different among samples when comparing offshore platform against rocky shores samples (mean $\mathrm{Hd}_{\text {platforms }}=0.942 \pm 0.023$, mean $\mathrm{Hd}_{\text {natural }}=0.982 \pm 0.019, \quad P=0.006 ; \quad$ mean $\pi_{\text {platforms }}$ $=0.0245 \pm 0.002, \quad$ mean $\quad \pi_{\text {natural }}=0.0364 \pm 0.010$, $P=0.045$; mean $k_{\text {platforms }}=10.27 \pm 0.88$, mean $k_{\text {natural }}=$ $15.24 \pm 4.05, P=0.045$, Fig. 2).

The Bayesian tree (Fig. 3) revealed two highly supported and reciprocally monophyletic clades (both with $100 \%$ posterior probability). Clade 2 was only represented by two haplotypes that were found in Taranto (H125) and Trieste (H144). Clade 1 included a number of supported subclades (PP $>95 \%)$ as well as paraphyletic haplotypes. The mean net divergence between the two main $P$. triqueter clades was $12.40 \pm 1.46 \%$ and $20.92 \pm 1.73 \%$ between $P$. triqueter and P. lamarkii.

The minimum spanning network (MSN) showing the most parsimonious branch connections at the $95 \%$ level 
Table 1 Spatial distribution of the Pomatoceros triqueter mtCOI haplotypes and genetic diversity per sample

\begin{tabular}{|c|c|c|c|c|c|c|c|c|c|c|c|c|c|c|c|c|c|}
\hline & AGO & AME & ANE & ANG & ANT & ARM & CER & GAR & PAG & PC80 & PCC & BRI & TAR & TEG & TRI & ZAG & Total \\
\hline $\mathrm{H} 1$ & 5 & 4 & 3 & 5 & 3 & 6 & 2 & 4 & 4 & 5 & 1 & 1 & 2 & 6 & 2 & 5 & 58 \\
\hline $\mathrm{H} 2$ & 2 & 4 & 2 & 6 & 4 & 2 & 5 & 6 & 3 & 1 & 4 & & 1 & 2 & & 2 & 44 \\
\hline $\mathrm{H} 3$ & 2 & 3 & 4 & 1 & 2 & 1 & 3 & 3 & 2 & 2 & 3 & 1 & 2 & & & 2 & 31 \\
\hline $\mathrm{H} 4$ & 1 & 1 & 1 & 2 & & 1 & 3 & 1 & 1 & 3 & & 1 & 1 & & 1 & & 17 \\
\hline H5 & & 1 & 1 & & 1 & & & 1 & 1 & & 2 & 1 & 1 & & & 4 & 13 \\
\hline H6 & & & 1 & & 1 & 1 & & 1 & 1 & & 1 & & & & & & 6 \\
\hline H7 & & & & 1 & & 2 & 1 & & & & & 1 & & & & 1 & 6 \\
\hline H8 & & & & 1 & 1 & & & & 1 & & & & & & 1 & & 4 \\
\hline H9 & & 1 & & & & & & 2 & & & & & & & & 1 & 4 \\
\hline $\mathrm{H} 10$ & & 1 & & & & 1 & & & 1 & & & & & 1 & & & 4 \\
\hline H11 & & 1 & & & 1 & & & & & & & & & & 1 & & 3 \\
\hline H12 & & & & & & & 1 & & 1 & & & & & 1 & & & 3 \\
\hline H13 & & 1 & & & & & 1 & & & & & & & & & & 2 \\
\hline H14 & & & 1 & & 1 & & & & & & & & & & & & 2 \\
\hline H15 & & & & & 1 & & & 1 & & & & & & & & & 2 \\
\hline H16 & & & & & & & & & & & 1 & 1 & & & & & 2 \\
\hline H17 & & & 1 & 1 & & & & & & & & & & & & & 2 \\
\hline H18 & & 1 & & & & & & & & & 1 & & & & & & 2 \\
\hline H19 & & & 1 & & & & & & & 1 & & & & & & & 2 \\
\hline $\mathrm{H} 20$ & & & & & 1 & & & & & & & 1 & & & & & 2 \\
\hline $\mathrm{H} 21$ & & & & & & & 1 & & & & & & & 1 & & & 2 \\
\hline $\mathrm{H} 22-\mathrm{H} 28$ & 7 & & & & & & & & & & & & & & & & 7 \\
\hline H29-H37 & & 9 & & & & & & & & & & & & & & & 9 \\
\hline H38-H49 & & & 12 & & & & & & & & & & & & & & 12 \\
\hline H50-H57 & & & & 8 & & & & & & & & & & & & & 8 \\
\hline H58-H66 & & & & & 9 & & & & & & & & & & & & 9 \\
\hline H67-H75 & & & & & & 9 & & & & & & & & & & & 9 \\
\hline H76-H82 & & & & & & & 7 & & & & & & & & & & 7 \\
\hline H83-H88 & & & & & & & & 6 & & & & & & & & & 6 \\
\hline H89-H96 & & & & & & & & & 8 & & & & & & & & 8 \\
\hline H97-H104 & & & & & & & & & & 8 & & & & & & & 8 \\
\hline H105-H117 & & & & & & & & & & & 13 & & & & & & 13 \\
\hline H118-H121 & & & & & & & & & & & & 4 & & & & & 4 \\
\hline H122-H130 & & & & & & & & & & & & & 9 & & & & 9 \\
\hline H131-H137 & & & & & & & & & & & & & & 7 & & & 7 \\
\hline H138-H146 & & & & & & & & & & & & & & & 9 & & 9 \\
\hline H147-H160 & & & & & & & & & & & & & & & & 14 & 14 \\
\hline$N$ & 17 & 27 & 27 & 25 & 25 & 23 & 24 & 25 & 23 & 20 & 26 & 11 & 16 & 18 & 14 & 29 & 350 \\
\hline$H$ & 11 & 19 & 21 & 15 & 19 & 16 & 15 & 14 & 17 & 13 & 20 & 11 & 14 & 12 & 13 & 20 & 160 \\
\hline $\mathrm{Hd}$ & 0.912 & 0.957 & 0.972 & 0.913 & 0.967 & 0.933 & 0.938 & 0.917 & 0.96 & 0.926 & 0.969 & 1 & 0.983 & 0.895 & 0.989 & 0.956 & 0.945 \\
\hline$\pi$ & 0.023 & 0.026 & 0.024 & 0.026 & 0.027 & 0.022 & 0.025 & 0.024 & 0.026 & 0.021 & 0.026 & 0.028 & 0.04 & 0.022 & 0.048 & 0.029 & 0.027 \\
\hline$k$ & 9.69 & 10.93 & 10.04 & 11.04 & 11.31 & 9.05 & 10.64 & 9.96 & 10.71 & 8.61 & 11.03 & 11.71 & 16.94 & 9.111 & 20.17 & 12.15 & 11.34 \\
\hline
\end{tabular}

Abbreviations of sampling sites as on Fig. 1; BRI Brindisi, TAR Taranto, TEG Tegnue di Chioggia, TRI Trieste and ZAG Zaglav, $N$ number of individuals, $H$ number of haplotypes, $H d$ haplotype diversity, $\pi$ nucleotide diversity, $k$ mean number of pairwise differences

also revealed the presence of two networks (Fig. 4) that could not be connected since haplotypes 125 and 144 were too divergent from the rest of the haplotypes (69 substitutions out of $419 \mathrm{bp}$ ). The bigger network showed a partition in two groups that were connected by haplotypes exclusively found in Taranto (H127, H128 and H129). Apart from these haplotypes, the two sub-networks were connected by a minimum of 13 mutation steps. The haplotypes found within the sub-networks were not specific of any geographical location, and all three sub-networks were 

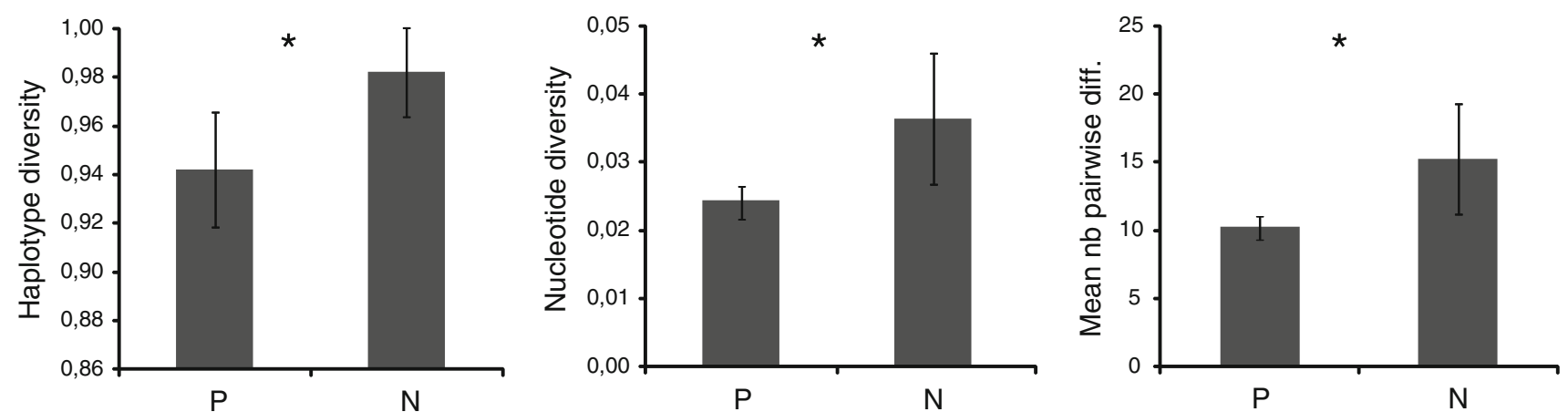

Fig. 2 Average haplotype diversity, nucleotide diversity and mean number of pairwise differences among mtCOI sequences of Pomatoceros triqueter over all platform samples $(\mathrm{P})$ and natural rocky shore samples $(\mathrm{N}) . * P<0.05$ (Wilcoxon test)

sympatric. The MSN revealed a star-like structure within each sub-networks, with central haplotypes shared among several samples and singletons diverging by only few substitutions from the central haplotypes.

No significant genetic structure was observed overall samples $\left(\Phi_{\mathrm{ST}}=0.0177, P=0.073\right)$, with $1.77 \%$ of the total variance being found among the 16 samples. The pairwise $\Phi_{\mathrm{ST}}$ estimates among samples ranged from 0 to $0.223(P=0.004)$ between Tegnue di Chioggia and Garibaldi platform, but none of the pairwise comparisons were significant after adjustment of the significance level $\alpha=0.05$ according to the sequential Bonferroni correction (data not shown). The AMOVAs conducted revealed no significant partition of the variance when considering offshore platforms versus natural substrates or north versus south Adriatic samples $(P>0.05$, data not shown).

\section{Discussion}

Deep mitochondrial phylogeny or evidence of cryptic species?

The genetic divergence observed between Pomatoceros triqueter and its closely related species Pomatoceros lamarckii, also present in the Adriatic Sea, was about $20 \%$. These two species are well differentiated on the basis of the operculum morphology (Zibrowius 1968), their karyotype (Dixon et al. 1998) and genetics (Ekaratne et al. 1982; Crisp and Ekaratne 1984). The genetic analyses conducted on a fragment of the mtDNA COI gene revealed the presence of two deep (12\% divergent) monophyletic clades in $P$. triqueter within the Adriatic Sea. No morphological differences were observed between the individuals belonging to the two deep monophyletic clades. Shape differences of the operculum were observed among all 350 individuals but fell in those described in the literature (Zibrowius 1968; Dixon et al. 1998) and were not related to specific clades. The sympatric occurrence of highly divergent mitochondrial clades has already been observed in other polychaete tubeworms in European seas, with similarly high net genetic divergences among clades (16.4\% divergence between two sympatric clades of Pectinaria koreni and $16 \%$ divergence between two sympatric clades of Owenia fusiformis; Jolly et al. 2006). Therefore, we considered the two uncovered monophyletic clades as belonging to Pomatoceros triqueter and thus rejected the occurrence of a possible cryptic species in our data set.

The phylogenetic analysis also recovered divergent groups of haplotypes, which formed a well-supported clade (Bayesian analysis: $\mathrm{PP}=100 \%$, mean of $12 \%$ genetic divergence, two subnetworks in the MSN). The occurrence of divergent groups of sequences within Pomatoceros triqueter may be attributed to different glacial relicts, resulting from geographical isolation of $P$. triqueter populations during lowered sea levels followed by a recent colonization from different ancestral populations located in the Mediterranean Sea, as observed for numerous marine organisms (Lee 2000; Schroth et al. 2002; Goetze 2003; Peijnenburg et al. 2004). Investigating the phylogeographic patterns of $P$. triqueter at the European scale may permit identifying the locations from which relic haplotypes arose.

May the introduction of platforms enhanced genetic connectivity?

The absence of significant pairwise comparisons and significant structure among various groups of samples may have several explanations. The first one is that the $\mathrm{mtCOI}$ gene may not be the best molecular marker to reveal potential genetic structure among Pomatoceros triqueter samples due to a high number of singletons and low number of shared haplotypes. The way to test for this hypothesis would be to use additional polymorphic nuclear markers such as microsatellites loci in order to test for 
Fig. 3 Bayesian phylogeny of $160 \mathrm{mtCOI}$ haplotypes of Pomatoceros triqueter rooted with P. lamarkii. Posterior probability $\geq 95 \%$ is indicated. Haplotypes are coded according to Table 1

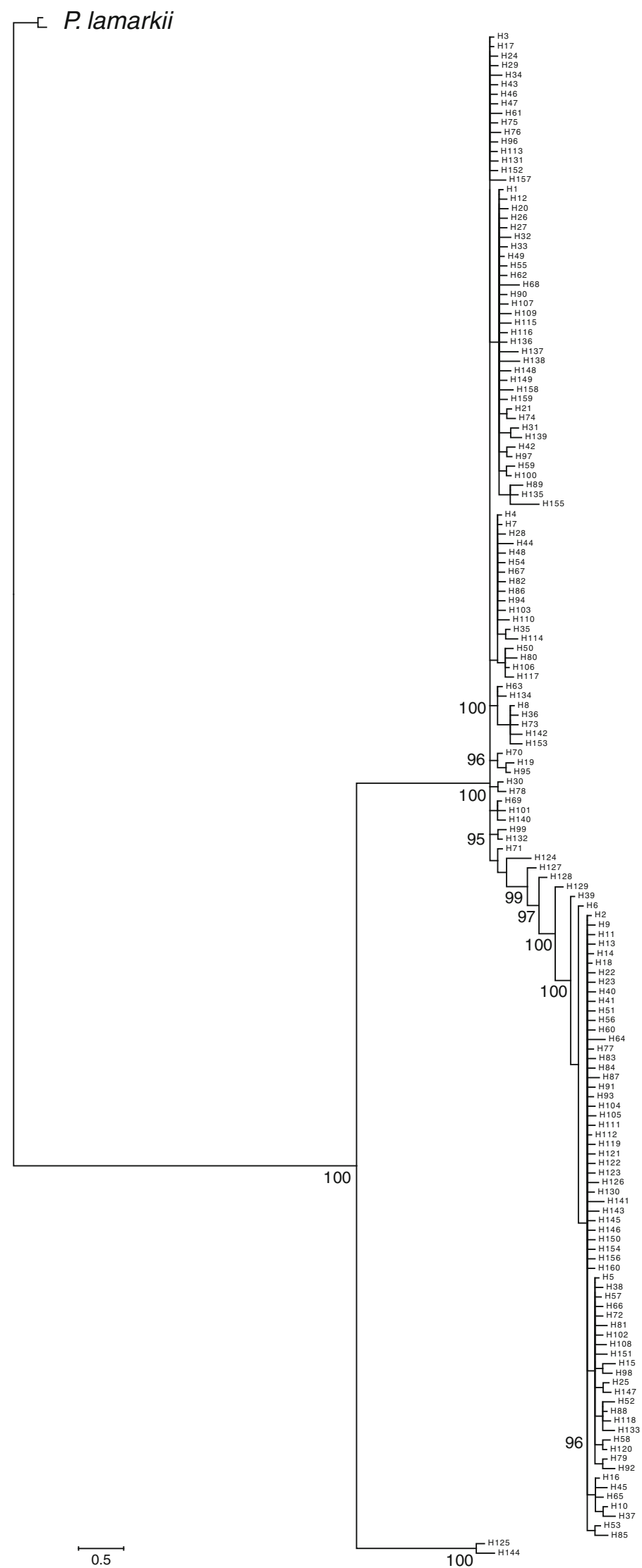




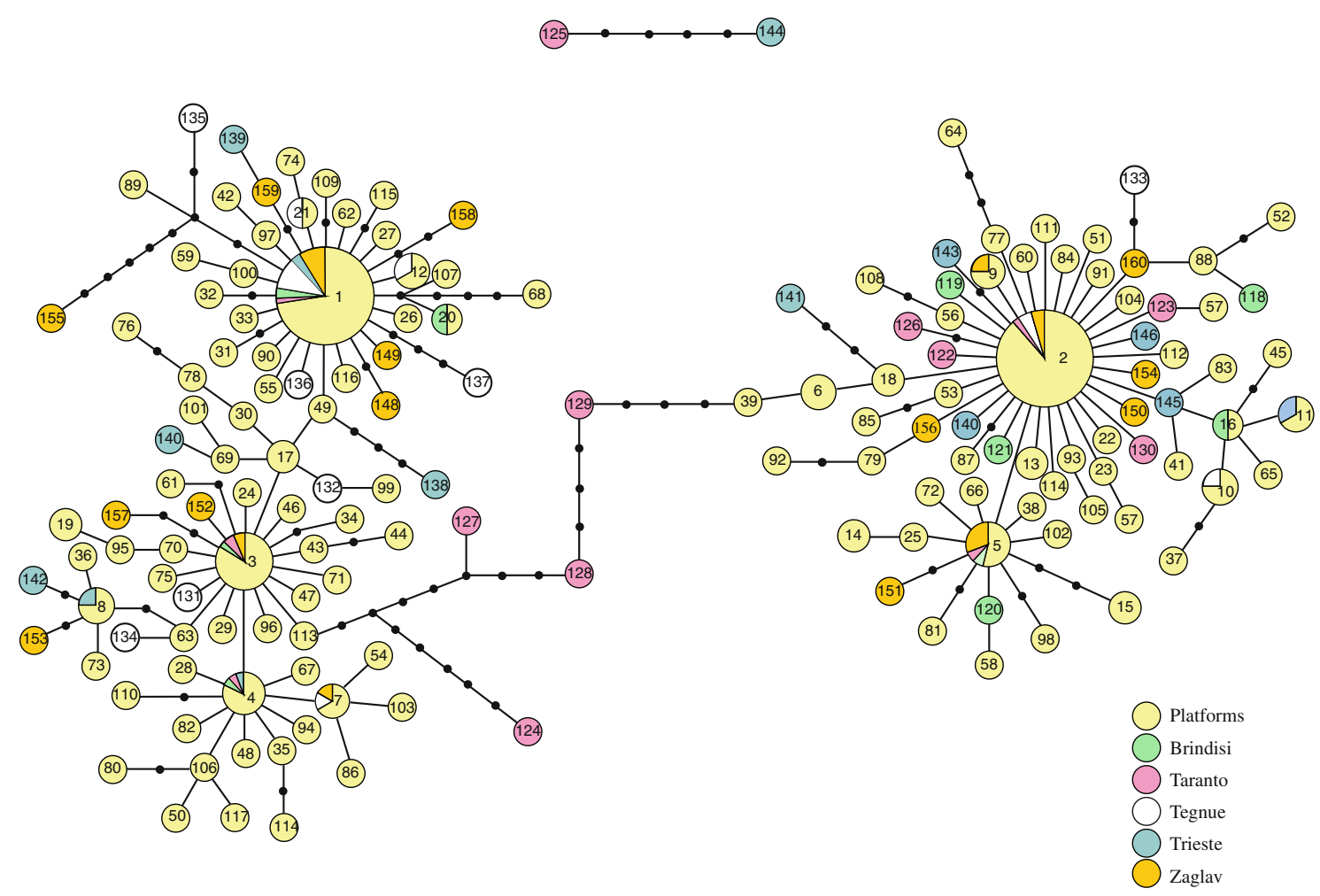

Fig. 4 Minimum spanning network illustrating the phylogenic relationships among the $160 \mathrm{mtCOI}$ haplotypes of Pomatoceros triqueter. Circles represent haplotypes with their corresponding number as in Table 1, while small black circles represent missing haplotypes within

significant differences among samples. However, we believe that if there would have been a significant partition of the genetic variation, mtDNA COI haplotypes would not appear randomly spatially distributed.

A second explanation for the lack of significant structuring of the samples would be that Pomatoceros triqueter populations were genetically connected prior the introduction of the platforms. This could be the result of a rather long larval duration of $P$. triqueter (about 3 weeks), which would allow sufficient gene flow among samples to homogenize genetic structure within the Adriatic Sea. Similar patterns have been observed (using more fast evolving nuclear markers) in the same area for the limpet Patella caerulea (Fauvelot et al. 2009), a species inhabiting natural rocky shores as well as artificial substrates along the shore (e.g. breakwaters). Alternatively, the observed genetic structure at the mtCOI may depict the footprint of the recent colonization of the Adriatic Sea after the Last Glacial Maximum (LGM). Indeed, during the LGM (about 18,000 ya), the sea level was about $100 \mathrm{~m}$ below the actual mean water level, and most of the Adriatic Sea bed was dried (Dondi et al. 1985; Thiede 1978). The sea water invaded the Adriatic during the last 10,000 years, and the colonization by the marine flora and fauna is very recent. the network (i.e. haplotypes not encountered within the samples). Each line linking two circles represents one base pair substitution along the 419-bp length-analysed sequence. The locations of the haplotypes are indicated with color code as in the legend (color figure online)

Genetic similarities in Adriatic samples of $P$. triqueter may reflect past founder effects linked with the colonization of the Adriatic Sea after the Pleistocene glaciation. Indeed, several studies have recently stressed the relevance of palaeoecological events in determining the genetic patterns in marine populations (e.g. Fauvelot et al. 2003; Wilson 2006; Imron et al. 2007; Virgilio et al. 2009). Interestingly, intermediate haplotypes between the two observed sub-networks are only located at the Taranto locality, suggesting that this part of Italy may have been a refuge for the Adriatic fauna during lowered sea levels.

A last explanation would be that platforms act as stepping stones for hard-bottom species, and thus the introduction of platforms has created corridors among former discrete natural populations. Because we did not have samples from natural rocky shores prior the introduction of all artificial structures nowadays found in the Adriatic Sea, it is impossible to conclude that artificial structures are responsible for the genetic connectivity currently observed for both Pomatoceros triqueter and Patella caerulea (Fauvelot et al. 2009). A possible way to test for genetic connectivity increase due to the platforms would be to conduct a study on $P$. triqueter genetic structure in an area where only discrete populations occur on natural shores 
and where no artificial structures may connect them, in order to estimate the dispersal kernel of $P$. triqueter in none impacted environments. Unfortunately, such areas likely do not exist anymore (Airoldi and Beck 2007).

Do the platforms affect the genetic diversity of $P$. triqueter?

Significantly smaller genetic diversity was observed in Pomatoceros triqueter samples located on the platforms as compared to natural rocky shore samples. Lower genetic diversity levels on artificial urban structures as compared to natural rocky shores have already been observed in another invertebrate sampled in the same area, Patella caerulea (Fauvelot et al. 2009). It has been evidenced that artificial structures support assemblages that differ significantly in composition, structure, reproductive output, patterns of recruitment and population dynamics from assemblages on nearby natural rocky habitats (see Bulleri and Chapman 2010 for a review) suggesting important functional and ecological differences between artificial and natural habitats. At the population level, the propagule pressure (Lockwood et al. 2005) through small inoculum size (i.e. the number of viable settlers) creates a filter from the amount of genetic diversity found in surrounding natural populations, further causing genetic diversity to decrease while maintaining genetic homogeneity between artificial and natural populations (Roman and Darling 2007). Our results support this hypothesis.

Lower levels of haplotype diversity have also already been found on meiobenthic harpaticoids (Copepoda) populations living near platforms $(<50 \mathrm{~m})$ as compared to distant populations $(>3 \mathrm{~km}$ ) in the Gulf of Mexico (Street and Montagna 1996). In this study, the low genetic diversity in samples near platforms was likely attributed to high concentrations of potentially toxic substances (hydrocarbons and trace metals) in the sand content, but no alternative hypothesis was proposed. Reductions in genetic diversity of Pomatoceros triqueter populations on platforms could similarly be attributed to extraction activities (i.e. pollution, Gorbi et al. 2008), and/or periodical removal of mussel beds (for commercial mussel exploitation and cleaning of fouling) on which $P$. triqueter grow, creating local bottlenecks (England et al. 2003). Eventually, the lower genetic diversity on artificial substrata as compared to natural ones may not be a result of a single factor but could likely be the consequence of a combination of these various processes.

\section{Conclusion}

All together, our results suggest that the phylogeographic patterns observed for Pomatoceros triqueter in the Adriatic
Sea based on mtCOI gene likely reflect the interaction between historical events (associated with Pleistocene sea level changes) and contemporary gene flow. The samples collected on platforms showed lower genetic diversity than those collected on the natural rocky shores. Our results contribute to the growing body of evidence showing that although artificial structures attract and support species typical of hard bottoms, they are not analogues of natural rocky habitats (see among others Bulleri 2005; Glasby and Connell 1999; Moreira et al. 2006; Moschella et al. 2005; Fauvelot et al. 2009). Our study calls for additional investigations related to the local functional and ecological processes that act on populations in a fragile marine ecosystem increasingly impacted by anthropogenic activities.

Acknowledgments This work was supported by the EU project EUMAR (European Marine Genetic Biodiversity-EVK3CT200100048) and by the AGIP funded research project BIOMARE (Project for the development of methodologies for monitoring the impact of off-shore structures in the northern Adriatic). We thank M. Pierpaoli for assistance in the lab. We are grateful to the Cooperative Society 'La Romagnola' (Marina di Ravenna) and to all the people that helped collecting samples.

\section{References}

Airoldi L, Beck MW (2007) Loss, status and trends for coastal marine habitats of Europe. Ocean Mar Biol Ann Rev 45:345-405

Airoldi L, Bacchiocchi F, Cagliola C, Bulleri F, Abbiati M (2005) Impact of recreational harvesting on assemblages in artificial rocky habitats. Mar Ecol Prog Ser 299:55-66

Bomkamp RE, Page HM, Dugan JE (2004) Role of food subsidies and habitat structure in influencing benthic communities of shell mounds at sites of existing and former offshore oil platforms. Mar Biol 146:201-211

Bulleri F (2005) Role of recruitment in causing differences between intertidal assemblages on seawalls and rocky shores. Mar Ecol Prog Ser 287:53-65

Bulleri F, Chapman MG (2010) The introduction of coastal infrastructure as a driver of change in marine environments. J Appl Ecol 47:26-35

Castric-Fey A (1984) Contribution à l'étude de la sexualité chez Pomatoceros lamarckii et Pomatoceros triqueter en baie de Concarneau (Sud Finistère). Ann Inst Océanogr Paris 60:163-187

Clement M, Posada D, Crandall KA (2000) TCS: a computer program to estimate gene genealogies. Mol Ecol 9:1657-1659

Connell SD (2001) Urban structures as marine habitats: an experimental comparison of the composition and abundance of subtidal epibiota among pilings, pontoons and rocky reefs. Mar Environ Res 52:115-125

Consoli P, Azzurro E, Sara G et al (2007) Fish diversity associated with gas platforms: evaluation of two underwater visual census techniques. Cienc Mar 33:121-132

Cotter E, O'Riordan RM, Myers AA (2003) Recruitment patterns of serpulids (Annelida: Polychaeta) in Bantry Bay, Ireland. J Mar Biol Assoc UK 83:41-48

Crema R, Prevedelli D, Castelli A (2001) Effect of submerged structures on the diversity of macrozoobenthos in the northern Adriatic Sea. In: Faranda FM, Guglielmo G, Spezie G (eds) Mediterranean ecosystem: structure and processes. Springer, New York, pp 367-374 
Crisp DJ (1974) Factors influencing the settlement of marine invertebrate larvae. In: Grant PT, Mackie AM (eds) Chemoreception in marine organisms. Academic Press, London, pp 177-265

Crisp DJ, Ekaratne K (1984) Polymorphism in Pomatoceros. Zool J Linn Soc 80:157-175

Dixon DR, Pascoe PL, Dixon LRJ (1998) Karyotypic differences between two species of Pomatoceros, $P$. triqueter and $P$. lamarckii (Polychaeta: Serpulidae). J Mar Biol Ass UK 78:11131126

Dondi L, Rizzini A, Rossi P (1985) Recent geological evolution of the Adriatic Sea. In: Stanley DJ, Wezel FC (eds) Geological evolution of the Mediterranean basin. Springer, New York, pp 195-214

Ekaratne K, Burfitt AH, Flowerdew MW, Crisp DJ (1982) Separation of two Atlantic species of Pomatoceros, P. triqueter and $P$. lamarckii (Annelida: Serpulidae) by means of biochemical genetics. Mar Biol 71:257-264

England PR, Osler GHR, Woodworth LM et al (2003) Effects of intense versus diffuse population bottleneck. Cons Gen 4: 595-604

Excoffier L, Smouse PE, Quattro JM (1992) Analysis of molecular variance inferred from metric distances among DNA haplotypes: application to human mitochondrial DNA restriction data. Genetics 131:479-491

Excoffier L, Laval G, Schneider S (2005) Arlequin ver. 3.0: an integrated software package for population genetics data analysis. Evol Bioinf Online 1:47-50

Fabi G, Grati F, Lucchetti A, Trovatelli L (2002) Evolution of the fish assemblage around a gas platform in the northern Adriatic Sea. ICES J Mar Sci 59:S309-S315

Fabi G, Grati F, Puletti M, Scarcella G (2004) Effects on fish community induced by installation of two gas platforms in the Adriatic Sea. Mar Ecol Prog Ser 273:187-197

Fauvelot C, Bernardi G, Planes S (2003) Reductions in the mitochondrial DNA diversity of coral reef fish provide evidence of population bottlenecks resulting from Holocene sea-level change. Evolution 57:1571-1583

Fauvelot C, Bertozzi F, Costantini F, Airoldi L, Abbiati M (2009) Lower genetic diversity in the limpet Patella caerulea on urban coastal structures compared to natural rocky habitats. Mar Biol 156:2313-2323

Folmer O, Black M, Hoeh W, Lutz R, Vrijenhoek R (1994) DNA primers for amplification of mitochondrial cytochrome $c$ oxidase subunit I from diverse metazoan invertebrates. Mol Mar Biol Biotechnol 3:294-299

Glasby TM, Connell SD (1999) Urban structures as marine habitats. Ambio 28:595-598

Goetze E (2003) Cryptic speciation on the high seas; global phylogenetics of the copepod family Eucalanidae. Proc R Soc Lond B 270:2321-2331

Gorbi S, Virno Lamberti C, Notti A, Benedetti M, Fattorini D, Moltedo G, Regoli F (2008) An ecotoxicological protocol with caged mussels, Mytilus galloprovincialis, for monitoring the impact of an offshore platform in the Adriatic sea. Mar Environ Res 65:34-49

Gorbi S, Benedetti M, Virno Lamberti C, Pisanelli B, Moltedo G, Regoli F (2009) Biological effects of diethylene glycol (DEG) and produced waters (PWs) released from offshore activities: a multi-biomarker approach with the sea bass Dicentrarchus labrax. Environ Pollut 157:3166-3173

Grant A, Briggs AD (2002) Toxicity of sediments from around a North Sea oil platform: are metals or hydrocarbons responsible for ecological impacts? Mar Environ Res 53:95-116

Halanych KM, Janosik AM (2006) A review of molecular markers used for Annelid phylogenetics. Integr Comp Biol 46:533-543
Hall TA (1999) BioEdit: a user-friendly biological sequence alignment editor and analysis program for Windows 95/98/NT. Nuc Acids Symp Ser 41:95-98

Hayward PJ, Ryland JS (eds) (1995) Handbook of the marine fauna of North-West Europe. Oxford University Press, Oxford

Hillis DM, Moritz C (1990) Molecular systematics. Sinauer, Sunderland, MA

Huelsenbeck JP, Ronquist F (2001) MrBayes: Bayesian inference of phylogeny. Bioinformatics 17:754-755

Hughes AR, Inouye BD, Johnson MTJ, Underwood N, Vellend M (2008) Ecological consequences of genetic diversity. Ecol Lett 11:609-623

Imron JeVreyB, Hale P, Degnan BM, Degnan SM (2007) Pleistocene isolation and recent gene flow in Haliotis asinina, an IndoPacific vetigastropod with limited dispersal capacity. Mol Ecol 16:289-304

Jolly MT, Viard F, Gentil F, Thiebaut E, Jollivet D (2006) Comparative phylogeography of two coastal polychaete tubeworms in the Northeast Atlantic supports shared history and vicariant events. Mol Ecol 15:1841-1855

Kupriyanova EK (2003) Live history evolution in Serpulimorph polychaetes: a phylogenetic analysis. Hydrobiologia 496:105-114

Lee CE (2000) Global phylogeography of a cryptic copepod species complex and reproductive isolation between genetically proximate "populations". Evolution 54:2014-2027

Librado P, Rozas J (2009) DnaSP v5: a software for comprehensive analysis of DNA polymorphism data. Bioinformatics 25:14511452

Lockwood JL, Cassey P, Blackburn T (2005) The role of propagule pressure in explaining species invasions. Trends Ecol Evol 20:223-228

Lotze HK, Lenihan HS, Bourque BJ, Bradbury RH, Cooke RG, Kay MC, Kidwell SM, Kirby MX, Peterson CH, Jackson JBC (2006) Depletion, degradation, and recovery potential of estuaries and coastal seas. Science 312:1806-1809

Martin D, Bertasi F, Colangelo MA, de Vries M, Frost M, Hawkins SJ, Macpherson E, Moschella PS, Satta MP, Thompson RC, Ceccherelli VU (2005) Ecological impact of coastal defence structures on sediment and mobile fauna: evaluating and forecasting consequences of unavoidable modifications of native habitats. Coast Eng 52:1027-1051

Moreira J, Chapman MG, Underwood AJ (2006) Seawalls do not sustain viable populations of limpets. Mar Ecol Prog Ser 322: $179-188$

Moschella PS, Abbiati M, Åberg P, Airoldi L, Anderson JM, Bacchiocchi F, Bulleri F, Dinesen GE, Frost M, Gacia E, Granhag L, Jonsson PR, Satta MP, Sundelof A, Thompson RC, Hawkins SJ (2005) Low-crested coastal defense structures as artificial habitats for marine life: using ecological criteria in design. Coast Eng 52:1053-1071

Nei M (1987) Molecular evolutionary genetics. Columbia University Press, New York

Nei M, Li W-H (1979) Mathematical model for studying genetic variation in terms of restriction endonucleases. Proc Natl Acad Sci USA 76:5269-5273

Nicholas KB, Nicholas HB (1997) GeneDoc: a tool for editing and annotating multiple sequence alignments. Distributed by the authors

Nylander JAA (2004) MrModeltest version 2. Program distributed by the author. Evolutionary Biology Centre, Uppsala University, Uppsala, Sweden

Olden D, Poff NL, Douglas MR, Douglas ME, Fausch KD (2004) Ecological and evolutionary consequences of biotic homogenization. Trends Ecol Evol 19:18-24

Page HM, Dugan JE, Dugan DS, Richards JB, Hubbard DM (1999) Effects of an offshore oil platform on the distribution and 
abundance of commercially important crab species. Mar Ecol Prog Ser 185:47-57

Page HM, Dugan JE, Culver CS, Hoesterey JC (2006) Exotic invertebrate species on offshore oil platforms. Mar Ecol Prog Ser 325:101-107

Peijnenburg KTCA, Breeuwer JAJ, Pierrot-Bults AC, Menken SBJ (2004) Phylogeography of the planktonic chaetognath Sagitta setosa reveals isolation in European seas. Evolution 58:1472-1487

Ponti M, Abbiati M, Ceccherelli VU (2002) Drilling platforms as artificial reefs: distribution of macrobenthic assemblages of the "Paguro" wreck (northern Adriatic Sea). ICES J Mar Sci 59:S316-S323

Relini G, Tixi F, Relini M, Torchia G (1998) The macrofouling on offshore platforms at Ravenna. Int Biodeterior Biodegrad 41: $41-55$

Reusch TBH, Ehlers A, Hammerli A, Worm B (2005) Ecosystem recovery after climatic extremes enhanced by genotypic diversity. Proc Natl Acad Sci USA 102:2826-2831

Roman J, Darling JA (2007) Paradox lost: genetic diversity and the success of aquatic invasions. Trends Ecol Evol 22:454-464

Schroth W, Jarms G, Streit B, Schierwater B (2002) Speciation and phylogeography in the cosmopolitan marine moon jelly, Aurelia sp. BMC Evol Biol 2:1-10

Street GT, Montagna PA (1996) Loss of genetic diversity in Harpacticoida near offshore platforms. Mar Biol 126:271-282

Tajima F (1983) Evolutionary relationship of DNA sequences in finite populations. Genetics 105:437-460
Tamura K, Dudley J, Nei M, Kumar S (2007) MEGA4: molecular evolutionary genetics analysis (MEGA) software version 4.0. Mol Biol Evol 24:1596-1599

Teatini P, Baú D, Gambolati G (2000) Water-gas dynamics and coastal land subsidence over Chioggia Mare field, northern Adriatic Sea. Hydrogeol J 8:462-479

Terlizzi A, Bevilacqua S, Scuderi D, Fiorentino D, Guarnieri G, Giangrande A, Licciano M, Felline S, Fraschetti S (2008) Effects of offshore platforms on soft-bottom macro-benthic assemblages: a case study in a Mediterranean gas field. Mar Pollut Bull 56:1303-1309

Thiede J (1978) A glacial mediterranean. Nature 276:680-683

Virgilio M, Fauvelot C, Costantini F, Abbiati M, Backeljau T (2009) Deep phylogenetic splits and disjunct haplotype distribution suggest cryptic speciation in Hediste diversicolor (Polychaeta: Nereididae). Mol Ecol 18:1980-1994

Wilson AB (2006) Genetic signature of recent glaciations on populations of a near-shore marine fish species (Syngnathus leptorhynchus). Mol Ecol 15:1857-1871

Worm B, Barbier EB, Beaumont $\mathrm{N}$ et al (2006) Impacts of biodiversity loss on ocean ecosystem services. Science 314 : $787-790$

Zibrowius H (1968) Etude morphologique, systématique et écologique des serpulidae (Annelida, Polychaeta) de la région de Marseille. Rec Trav Stat Mar Endoume 43:81-252 